\title{
PENGELOLAAN LINGKUNGAN PADA KEGIATAN OPERASI TAMBANG DARAT BIJIH TIMAH MENGGUNAKAN METODE BOREHOLE MINING DI WIUP PT. TIMAH, TBK
}

\author{
Nomensen Ricardo $^{1)}$, Dewi Ayu Kusumaningsih ${ }^{2)}$ dan Teguh Nurhidayat ${ }^{1)}$ \\ 1) PT. TIMAH, Tbk \\ ${ }^{2)}$ PT. Studio Mineral Batubara
}

\begin{abstract}
ABSTRAK
Borehole mining (BHM) merupakan metode penambangan menggunakan aliran air bertekanan tinggi (water jet) dan dikombinasikan dengan sistem pemompaan slurry dari bawah tanah. Dalam upaya meningkatkan produksi bijih timah, PT. TIMAH, Tbk melakukan kegiatan penambangan menggunakan metode BHM. Pemilihan metode penambangan BHM bertujuan untuk menambang sumberdaya marginal tanpa memerlukan stripping overburden $(\mathrm{OB})$, dengan prinsip kerja: membuat lubang vertikal hingga dasar zona target menggunakan alat holemaker; dengan memanfaatkan tekanan water jet, air akan memberai material di sekelilingnya; saat material terberai, pompa tanah siap menghisap slurry hingga ke permukaan. Kapasitas penambangan efektif menggunakan metode BHM adalah $750 \mathrm{~m}^{3} / \mathrm{bulan}$, dengan jam jalan efektif alat $125 \mathrm{jam} / \mathrm{bulan}$. Kegiatan penambangan dengan metode BHM ini, berpotensi menimbulkan masalah lingkungan diantaranya terbentuknya lubang bekas penambangan (void) dan genangan air di sekitar lokasi tambang. Pemindahan tanah dari bawah permukaan pada kegiatan ore getting dengan volume 750 $\mathrm{m}^{3}$ dapat mengganggu struktur dan kekuatan tanah sehingga menyebabkan runtuhan/amblesan yang pada akhirnya menghasilkan void. Pengelolaan lingkungan yang tidak baik dapat menimbulkan masalah yang serius terhadap bentang lahan dan akan menimbulkan dampak turunan seperti masalah sosial. Perencanaan desain penutupan lahan dengan metode backfilling menjadi terobosan untuk mengatasi void yang ada. Prinsipnya, material yang akan diambil pada titik penambangan berikutnya ditransfer ke void sebelumnya yang telah terbentuk dan demikian seterusnya. Di samping itu, dilakukan revegetasi di sekitar lokasi penambangan BHM untuk meningkatkan daya dukung tanah. Limpasan air ke permukaan secara kontinu menyebabkan kondisi lahan sekitar menjadi lembab (jenuh air) sehingga daya dukung tanah menurun. Kegiatan penambangan menggunakan metode BHM di PT. TIMAH, Tbk memang merupakan suatu terobosan dalam konservasi cadangan bijih timah. Namun, aspek lingkungan juga menjadi hal yang perlu diperhatikan. Pengelolaan lingkungan yang tepat dapat meminimalkan masalah lingkungan yang terjadi. Lubang-lubang berdiameter 1,5 hingga 3 meter yang dihasilkan dapat diatasi dengan sistem back-filling. Limpasan air di permukaan diatasi dengan perencanaan sistem penirisan tambang yang terencana yaitu dengan pembuatan jalur/paritan di sekitar area penambangan.
\end{abstract}

Kata kunci: borehole mining, void, backfilling

\begin{abstract}
Borehole mining (BHM) is a mining method using high pressure water flow (water jet) and combined with an underground slurry pumping system. In an effort to increase tin ore production, PT. TIMAH, Tbk conducts mining activities using the BHM method. The selection of the BHM mining method aims to mine marginal resources without the need for stripping overburden $(O B)$, with the working principle: making vertical holes to the bottom of the target zone using a holemaker; by utilizing the pressure of a water jet, water will fill the surrounding material; when the material is dispersed, the ground pump is ready to suction the slurry to the surface. The effective mining capacity using the BHM method is $750 \mathrm{~m}^{3} /$ month, with effective road hours of 125 hours / month. Mining activities using the BHM method have the potential to cause
\end{abstract}


environmental problems including the forming of void pits and puddles around the mine site. Displacement of soil from below the surface in ore getting activities with a volume of $750 \mathrm{~m}^{3} \mathrm{can}$ disrupt the structure and strength of the soil, causing collapse / subsidence which eventually produces voids. Improper environmental management can cause serious problems for the landscape and will cause derivative impacts such as social problems. Land cover design planning with backfilling method is a breakthrough to overcome existing voids. In principle, the material to be taken at the next mining point is transferred to the previously formed voids and so on. In addition, revegetation was carried out around the BHM mining location to increase the carrying capacity of the soil. The runoff of water to the surface continuously causes the surrounding land to become moist (saturated with water) so that the carrying capacity of the soil decreases. Mining activities use the BHM method at PT. TIMAH, Tbk is indeed a breakthrough in the conservation of tin ore reserves. However, environmental aspects also need to be considered. Proper environmental management can minimize environmental problems that occur. The holes with a diameter of 1.5 to 3 meters produced can be overcome with a back-filling system. Surface runoff is overcome by planning a planned mine drainage system by making a path / trench around the mining area

Key Words: borehole mining, void, backfilling

\section{A. PENDAHULUAN}

\section{A.1. Latar Belakang}

PT. TIMAH Tbk merupakan Badan Usaha Milik Negara (BUMN) yang bergerak di bidang pertambangan timah, yang 65\% sahamnya dimiliki oleh Pemerintah Republik Indonesia dan 35\% sisanya dimiliki oleh masyarakat umum. PT. Timah Tbk memegang 120 Izin Usaha Pertambangan (IUP) dengan total luas 428.378,98 ha yang tersebar di Provinsi Kepulauan Bangka Belitung, serta Kepulauan Riau. Kegiatan yang menjadi bisnis utamanya adalah penambangan timah di laut dan di darat, serta pengolahan dan pemurnian bijih timah.

Penambangan endapan bijih timah di darat dilakukan dengan metode Hydraulic Mining secara Surface maupun Sub-Surface. Klasifikasi skala tambang yang terdapat di PT. Timah Tbk sesuai dengan tata cara dan tata laksana Penambangan Timah Darat adalah sebagai berikut: Tambang Besar (TB), Tambang Semprot (TS) dan Tambang Kecil (TK). Pada TK, sistem penambangan timah dilakukan pada cadangan dangkal yang tersebar dalam dimensi yang kecil atau spotted dengan kedalaman menurut data bor rata-rata $<15 \mathrm{~m}$. Pada TK ini juga digunakan metode sub surface mining menggunakan alat bore hole (BHM), yang diintegrasikan dengan pencucian terpisah yang disebut Tambang Kecil Terintegrasi (TKT).

Bore Hole Mining (BHM) adalah metode penambangan mineral/bijih timah melalui lubang bor dengan water cutting (jet pump) yang bertekanan tinggi yang dilakukan dari permukaan tanah. Alat Bor Hole Mining yang dirancang terdiri dari dua pompa, satu untuk memompa water cutting (jet pump) yang bertekanan tinggi dengan Mesin Pompa Air (MPA) dan yang kedua untuk menghisap material slurry kaksa dengan Mesin Pompa Tanah (MPT) yang merupakan hasil water cutting (jet pump) di lapisan kaksa. Dengan metode ini tidak perlu mengupas lapisan tanah atas/ overburden seperti yang dilakukan pada tambang semprot, sehingga biaya produksi dapat ditekan. Namun di sisi lain penambangan dengan metode BHM memberikan dampak pada lingkungan misalnya perubahan bentang lahan lokal, sehingga perlu dikaji lebih lanjut untuk melakukan pengelolaan lingkungan pada wilayah kerja penambangan metode BHM.

Pengelolaan lingkungan akibat kegiatan penambangan metode BHM dilakukan untuk mengantisipasi dampak yang meluas. Pembuatan skema dan tata kelola penambangan yang tepat dapat meminimalisir dampak amblesan. 


\section{A.2. Tujuan}

Tujuan dari penyusunan makalah ini adalah untuk merumuskan:

1. potensi dampak lingkungan akibat penambangan metode BHM; dan

2. bentuk pengelolaan lingkungan akibat kegiatan penambangan metode BHM.

\section{A.3. Pendekatan Pemecahan Masalah}

Metode kualitatif dan kuantitatif digunakan dalam kajian ini. Metode kuantitatif digunakan untuk menghitung laju pemindahan tanah oleh peralatan BHM. Metode kualitatif digunakan dalam mercancang skema/ layout penambangan metode BHM dalam pengelolaan lingkungan.

\section{B. LOKASI KAJIAN}

Lokasi kajian dilakukan di salah satu wilayah izin usaha pertambangan (WIUP) PT. Timah Tbk yaitu TB Nudur, Toboali, Bangka Selatan. (Gambar 1)

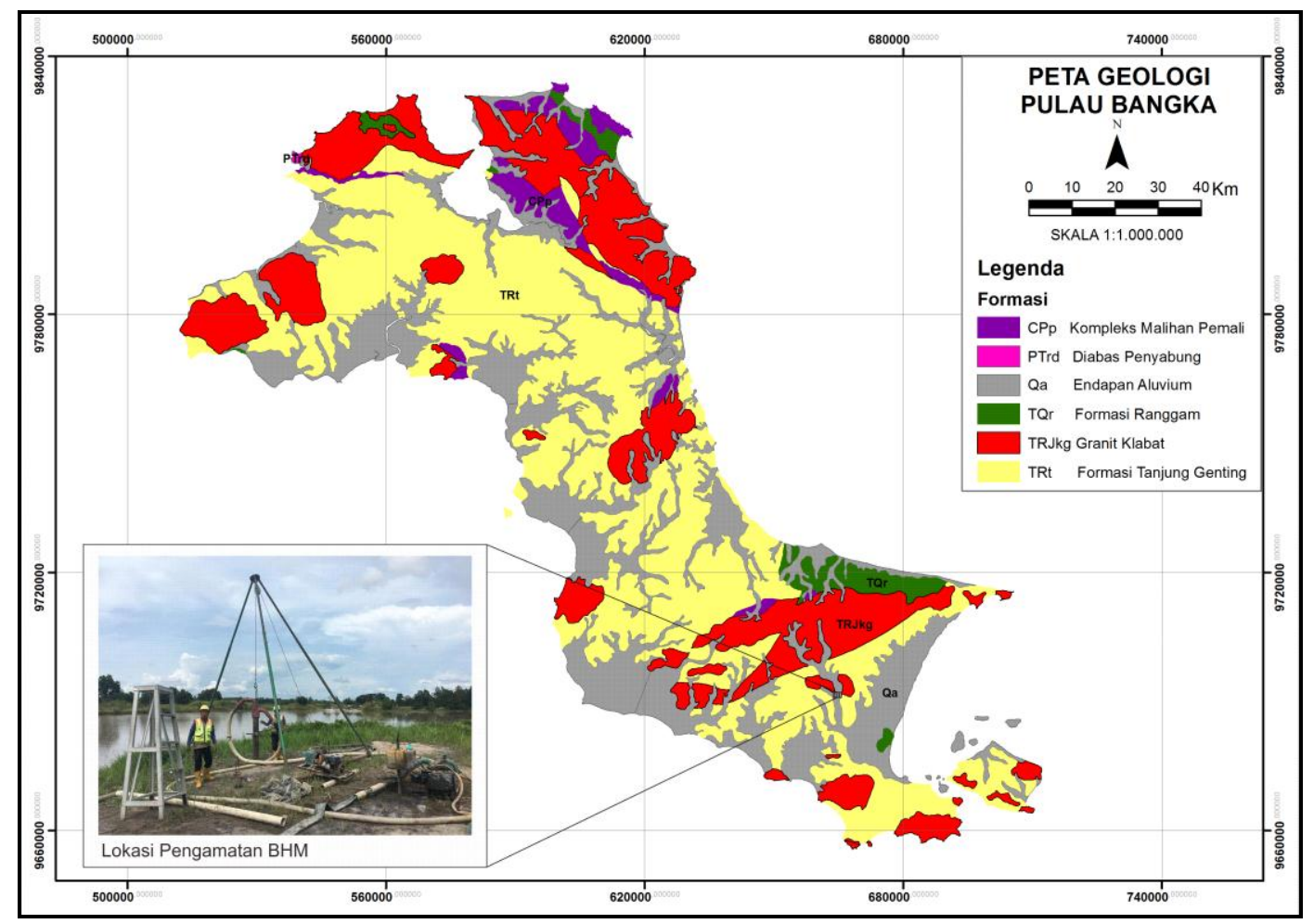

Gambar 1. Lokasi Kajian Tambang Metode BHM TB-Nudur, Toboali, Bangka Selatan

(Sumber Gambar : modifikasi dari Margono et.al,, 1995 dan Mangga \& Jamal, 1994)

\section{DESKRIPSI KEGIATAN}

Bore Hole Mining adalah metode penambangan mineral melalui lubang bor dengan water cutting (jet pump) yang bertekanan tinggi yang dilakukan dari permukaan tanah (Bojan, 2004). Alat borehole mining yang dirancang terdiri dari dua pompa, satu untuk memompa water cutting (jet рuтр) yang bertekanan tinggi dengan Mesin Pompa Air (MPA) dan yang kedua untuk menghisap material slurry kaksa dengan Mesin Pompa Tanah (MPT) yang merupakan hasil water cutting (jet рump) di lapisan kaksa. Pembukaan Tambang Kecil dengan metode BHM ini mempunyai tujuan untuk: menurunkan biaya operasi tambang, meningkatkan produksi, menambang pada cadangan spotted dan meningkatkan efisiensi penambangan. Skema urutan alur kerja menggunakan metode borehole mining adalah sebagai berikut: 
a. Sebuah lubang dibor dari permukaan tanah menggunakan alat holemaker (10 inch), dengan kedalaman sesuai yang direncanakan (sesuai kedalaman lapisan kaksa).

b. Pasang tripod alat BHM dan lakukan penyetelan penggerak winch.

c. Turunkan pipa BHM ke dalam lubang bor sampai nozzle mencapai kedalaman yang direncanakan.

d. Pasang swivel, hose monitor pompa air, dan hose isap pompa tanah.

e. Mesin Pompa Air (MPA) akan memompa water cutting (jet pump) yang bertekanan tinggi ke bawah permukaan (lubang bor) dan akan diteruskan secara horizontal melalui nozzle ke lapisan material (kaksa) yang akan ditambang.

f. Hasil water cutting (jet pump) di lapisan kaksa berupa material slurry akan dihisap dengan mesin pompa tanah dan di tampung di jumbo bag.

g. Material kaksa pada jumbo bag akan ditransportasikan ke washing plant untuk dilakukan peningkatan kadar Sn.

Kegiatan penambangan menggunakan metode BHM telah dilakukan oleh PT. Timah Tbk sejak tahun 2013 hingga saat ini. Keuntungan dari metode BHM adalah sebagai berikut (Ichwan et al, 2014):

a. Dapat dilakukan pada area penambangan yang sempit;

b. Tidak memerlukan pembersihan lahan;

c. Tidak ada kegiatan penggalian pada lapisan overburden;

d. Bijih timah dapat terambil dengan maksimal;

e. Periode penambangan dilakukan dalam waktu yang singkat;

f. Limbah penambangan yang dihasilkan sedikit; dan

g. Mudah dilakukan kegiatan reklamasi.

Tahap kegiatan selama pengoperasian alat penambangan borehole mining teridiri dari: persiapan sarana dan prasarana tambang serta penambangan timah menggunakan metode borehole mining.

\section{1) Persiapan Sarana dan Prasarana Tambang}

Kegiatan yang harus dilakukan dalam persiapan sarana dan prasarana tambang adalah:

- Penyediaan prasarana tambang berupa kantor, gudang, bedeng, rumah mesin, rumah pemanggangan timah dan rumah jaga.

- Penyediaan sarana tambang berupa jalan, jembatan, bandar, dam pengaman tambang, pagar pengaman instalasi pencucian, tutup sakhan, pagar pengeringan timah, pagar tangki BBM, kolam air kerja, tempat penimbunan tanah pucuk dan tempat penimbunan penambangan.

- Penyediaan peralatan dan bahan tambang BHM.

- Penyediaan kolong air yang dapat menampung air kerja untuk kelancaran operasi penambangan selama umur tambang di lokasi/daerah tersebut.

\section{2) Penambangan Timah metode bore hole mining}

Peralatan yang dibutuhkan untuk melakukan kegiatan penambangan dengan metode BHM, adalah sebagai berikut: a) alat BHM (swivel, pipa, nozzle); b) mesin pompa (tanah dan air/semprot); c) winch; dan d) alat hole maker. (Gambar 2)

Peralatan yang digunakan selama pengoperasian BHM terdiri dari: karung, hopper, excavator, alat sampling, truk, rangka jumbo bag/ karung, tripod $6 \mathrm{~m}$ winch, mata bor 6", swivel 6", pipa bor 6x1,5 $\mathrm{m}$, mesin pompa tanah $26 \mathrm{HP}\left(10 \mathrm{~m}^{3} / \mathrm{jam}\right)$, mesin pompa air $26 \mathrm{HP}\left(100 \mathrm{~m}^{3} / \mathrm{jam}\right)$, hose hisap 4" 6-8 $\mathrm{m}$, hose 3" water jet $100 \mathrm{~m}^{3} / \mathrm{jam}$, clamp pipa 6", hose terpal 4" 50-100 m, pipa PVC 4", hole maker.

Metode BHM merupakan cara penambangan timah yang dilakukan dari permukaan tanah melalui lubang bor menggunakan water cutting (jet pump) bertekanan tinggi untuk melumpurkan lapisan kaksa dan mesin pompa tanah untuk menyedot lumpur kaksa. Nozzle yang menyentuh lapisan kaksa memiliki radius semprot $\pm 3 \mathrm{~m}$. Cara ini dilakukan untuk lokasi-lokasi dengan overburden 
tebal (rata-rata 10-20 m) dan ketebalan kaksa 1-2 m. Hasil sedotan lumpur kaksa ditampung dalam jumbo bag dan kemudian dibawa ke washing plant untuk peningkatan kadar Sn. Keberadaan air dalam jumlah mencukupi menjadi syarat untuk penambangan metode BHM. Sketsa penambangan BHM disajikan pada Gambar 3.

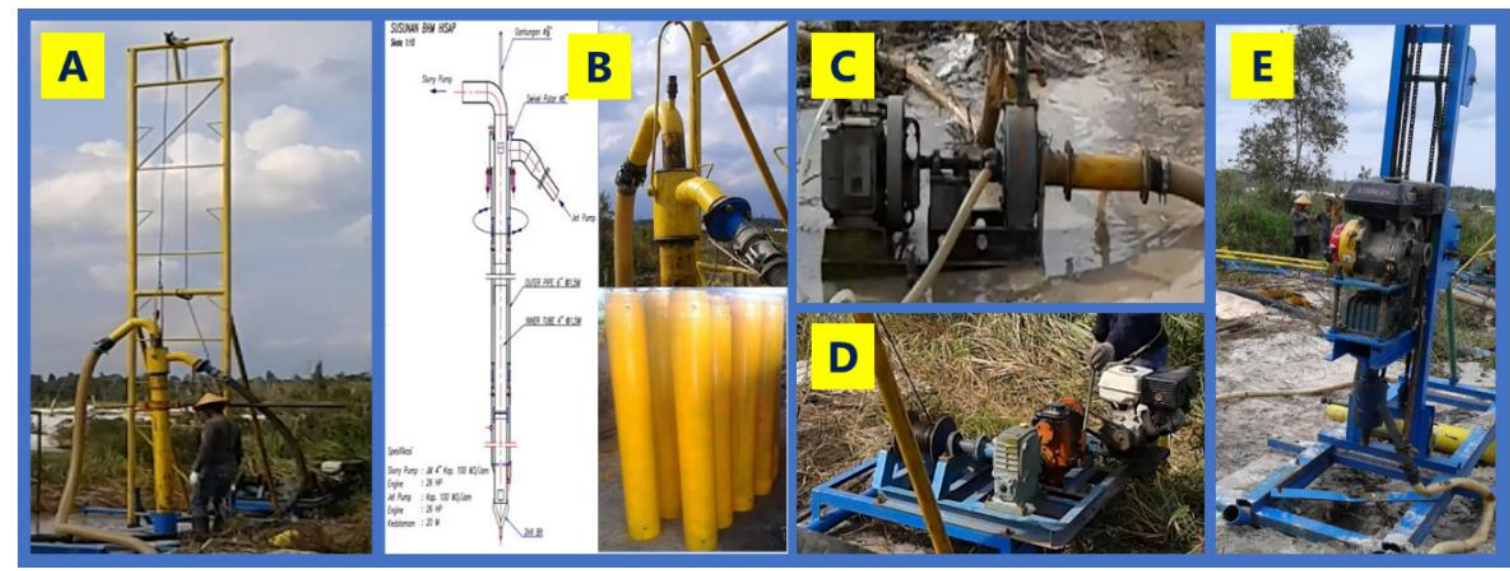

Gambar 2. (A) Rangkaian BHM; (B) Rancangan BHM; (C) Mesin Pompa Tanah; (D) Winch; (E) Hole Maker (Sumber Gambar : Re-FS TKT Borehole Mining)

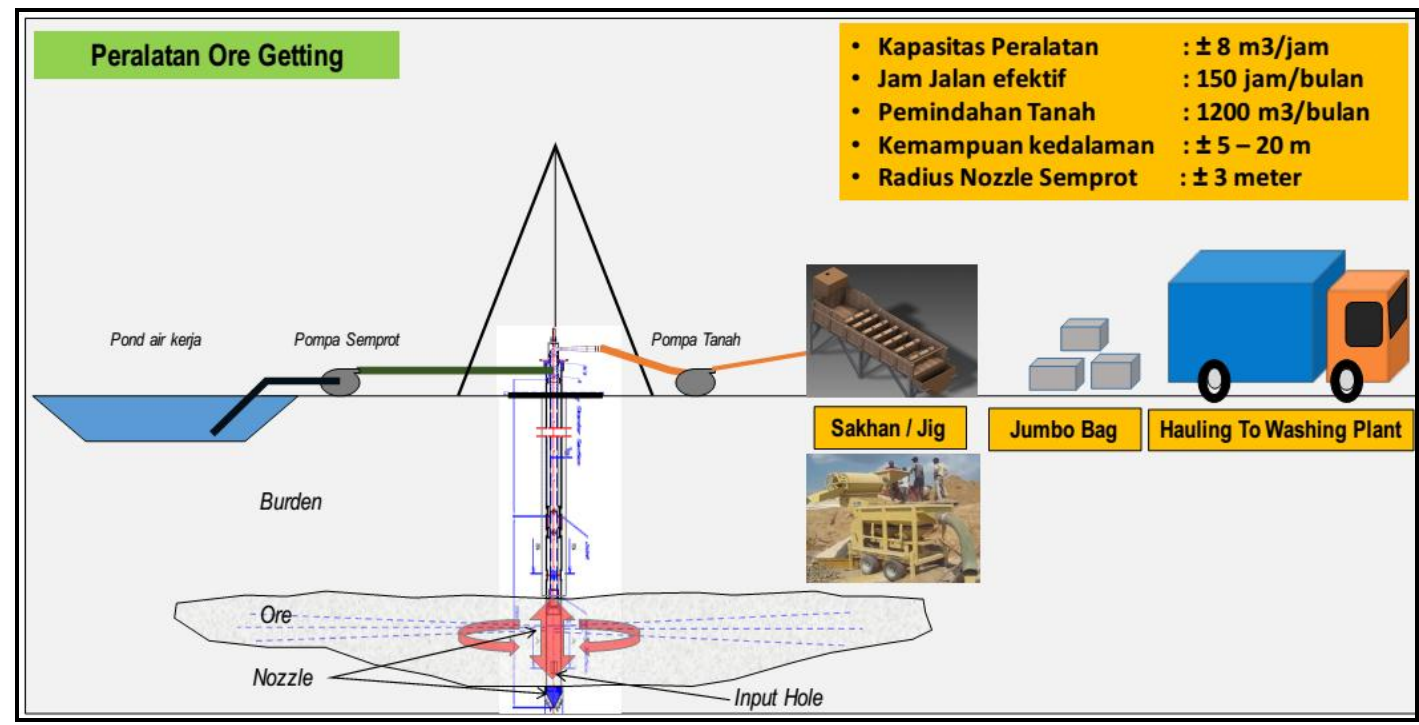

Gambar 3. Sketsa Penambangan Metode BHM (Sumber Gambar : Re-FS TKT BHM)

Penambangan dengan metode BHM, akan membentuk kolong-kolong. Meskipun tambang BHM tidak memerlukan pembersihan lahan dan pengupasan tanah pucuk, akibat kegiatan pengangkatan keluar material kaksa, dapat menyebabkan amblesan di permukaan sehinga terjadi gangguan terhadap bentang alam dan air tanah.

Pada saat kegiatan penambangan, lumpur kaksa disedot keluar dengan menggunakan pompa tanah. Dengan asumsi kemampuan radius semprot dari nozzle sebesar $3 \mathrm{~m}$ dan ketebalan lapisan kaksa 1-2 $\mathrm{m}$, maka jumlah lumpur kaksa yang dapat disedot ke luar sebesar maksimum $56,57 \mathrm{~m}^{3}$. Kapasitas pompa tanah menyedot lumpur kaksa adalah $\pm 8 \mathrm{~m}^{3} / \mathrm{jam}$, sehingga BHM beroperasi pada satu titik selama sekitar 7 jam. Sedotan lumpur kaksa ini akan meninggalkan rongga di dalam tanah dengan volume sekitar $56,57 \mathrm{~m}^{3}$. Operasi penambangan metode BHM dilakukan pada lokasi-lokasi dengan overburden tebal (10-20 m). 
Penambangan dengan metode BHM terdapat dua pilihan pencucian, yakni: 1) Bila jarak antara lokasi tambang dengan PPBT dekat, maka pencucian dilakukan di PPBT; 2) Bila lokasi tambang jauh dari PPBT, maka pada tapak tambang tersebut dibuat perangkat pencucian di tambang sebagaimana perangkat pencucian di tambang semprot, yakni dengan menggunakan prinsip gravitasi dengan air sebagai media. Peralatan yang digunakan adalah jig (primer, sekunder, dan tersier) dan saluran cuci (wasgot/palong) yang dibuat dari kayu papan. Sumber air pencucian diperoleh dari air yang tertampung di 'reservoir'. 'Reservoir' menampung air dari hasil sirkulasi, air hujan, dan dari aliran sungai terdekat. Kapasitas pencucian dengan PA jig mencapai $2,5 \mathrm{~m}^{3} / \mathrm{m}^{2}$ saringan efektif/jam, sementara bila menggunakan yuba jig dapat mencapai $3,0 \mathrm{~m}^{3} \mathrm{solid} / \mathrm{m}^{2}$ saringan efektif/jam. Sedang palong mempunyai kapasitas pengendapan $12,5 \mathrm{~m}^{3} / \mathrm{jam} / \mathrm{per}$ saluran. Letak jig dan palong harus sedekat mungkin dengan front kerja. Hasil akhir proses pencucian berupa konsentrat bijih timah dengan kadar 30-40 \% Sn. Timah hasil pencucian di lapangan selanjutnya di bawa ke Pusat Pencucian Bijih Timah (PPBT). Lumpur yang disedot pada tambang BHM adalah $8 \mathrm{~m}^{3} / \mathrm{jam}$ dengan break even grade $0,5 \mathrm{~kg} / \mathrm{m}^{3}$, sedangkan sisanya akan dibuang. Partikel-partikel berukuran pasir akan dibuang sebagai pasir sisa tambang, sedangkan partikelpartikel berukuran clay dan debu halus akan terdispersi dalam air pencucian. Namun karena proses pencucian ini dilakukan pada lingkungan tertutup, maka peluang untuk terjadinya sedimentasi di lingkungan seperti di pinggir-pinggir sungai, danau dan muara dapat dihindarkan.

Kapasitas penambangan efektif menggunakan $\mathrm{BHM} \pm 7 \mathrm{~m}^{3} / \mathrm{jam}$ dengan jam jalan efektif 150 $\mathrm{jam} /$ bulan, sehingga kapasitas perbulannya adalah $\pm 1.050 \mathrm{~m}^{3}$. Penambangan dengan metode BHM dapat dilakukan di seluruh wilayah IUP darat di Pulau Bangka dan Pulau Belitung. Rencana karya diberikan untuk lokasi dengan overburden tebal (rata-rata di atas 10-20 m), dengan ketebalan kaksa rata-rata 1-2 m. Penggunaan metode BHM pada penambangan TK membutuhkan 4 tenaga kerja untuk mengoperasikan masing-masing unitnya dengan 1 shift kerja. Jam kerja yang diterapkan adalah 8 jam/hari dan 25 hari kerja/bulan, sehingga total jam kerja adalah 200 jam/bulan.

\section{ASPEK TEKNIS METODE BORE HOLE MINING}

Pemindahan laju tanah (LPT) oleh peralatan borehole mining dipengaruhi oleh kecepatan aliran, jenis material, berat jenis material, kapasitas pompa. Pemindahan tanah (proses ore-getting) ke permukaan menyebabkan adanya ruang kosong (gerowong) di bawah permukaan sehingga mengakibatkan amblesan/ runtuhan. Keadaan yang terlalu jenuh berakibat pada penurunan gaya kohesi pada butiran. Secara teknis, gambar teknik peralatan BHM ditunjukkan pada Gambar 4.

Rekahan batuan selama proses BHM dapat dilakukan dengan metode berikut (Bondarchuk, 2004): hydrodynamic (water jet, hydropercussion dan depression) dan mekanik termasuk kombinasinya. Pengujian peralatan BHM dilakukan untuk mengetahui kecepatan aliran, debit aliran hingga laju pemindahan tanah. Pengujian ini dimaksudkan untuk memperkirakan seberapa besar volume lubang yang dihasilkan oleh satu kali penambangan menggunakan alat BHM.

\section{D.1. Uji Debit Aliran Air Sebelum Masuk Pipa BHM}

Pengukuran debit aliran air hasil pompa air sebelum memasuki pipa/swivel BHM menunjukkan debit secara berurutan $96,18 \mathrm{~m}^{3} / \mathrm{jam} ; 86,75 \mathrm{~m}^{3} / \mathrm{jam}$; dan $89,52 \mathrm{~m}^{3} / \mathrm{jam}$. Dengan luas penampang pipa/selang (4 inci) $0,0081 \mathrm{~m}^{2}$ maka diperkirakan kecepatan aliran antara 2,97 m/s hingga 3,30 m/s. (Tabel 1) 


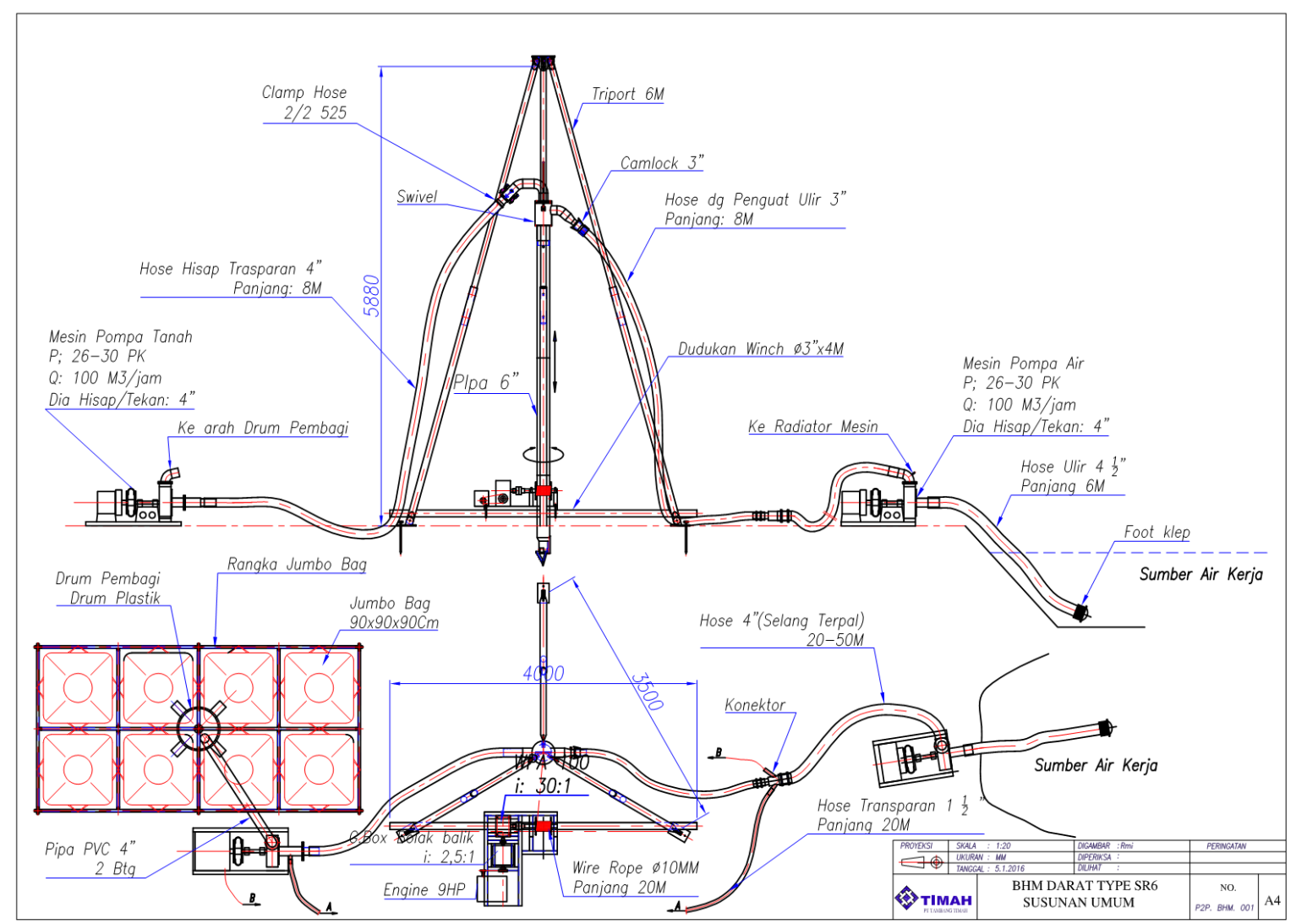

Gambar 4. Rancang Teknik Peralatan Borehole Mining (Sumber : Divisi KS-TIMAH)

Tabel 1. Uji Debit Aliran Air Sebelum Masuk Pipa BHM

\begin{tabular}{cccccccc}
\hline \multirow{2}{*}{ No } & \multirow{2}{*}{ Pengujian } & Kedalaman & \multicolumn{5}{c}{ Sebelum Masuk Pipa BHM } \\
\cline { 4 - 7 } & & Volume $\left(\mathbf{m}^{\mathbf{3}}\right)$ & Waktu $(\mathbf{s})$ & $\begin{array}{c}\text { Debit } \\
\mathbf{m}^{\mathbf{3}} / \mathbf{j a m}\end{array}$ & $\begin{array}{c}\text { Luas } \\
\text { Pipa }\left(\mathbf{m}^{\mathbf{2}}\right)\end{array}$ & $\begin{array}{c}\text { Kecepatan } \\
(\mathbf{m} / \mathbf{s})\end{array}$ \\
\hline 1 & Uji 1 & \multirow{2}{*}{ Uji di } & 0,14 & 5,24 & 96,18321 & 0,0081 & 3,30 \\
2 & Uji 2 & Permukaan & 0,14 & 5,81 & 86,74699 & 0,0081 & 2,97 \\
3 & Uji 3 & & 0,14 & 5,63 & 89,52043 & 0,0081 & 3,07 \\
\hline
\end{tabular}

\section{D.2. Uji Debit Aliran Slurry}

Pengukuran debit aliran slurry hasil pompa tanah setelah melalui selang sepanjang $10 \mathrm{~m}$ pada kedalaman 7,5 m menunjukkan debit secara berurutan 92,73 m/3am; 109,92 $\mathrm{m}^{3} / \mathrm{jam}$; dan 95,04 $\mathrm{m}^{3} /$ jam serta pada kedalaman $9 \mathrm{~m}$ menunjukkan debit secara berurutan $98,34 \mathrm{~m}^{3} / \mathrm{jam}$; 99,90 $\mathrm{m}^{3} / \mathrm{jam} ; 105,33 \mathrm{~m}^{3} / \mathrm{jam}$. (Tabel 2)

Tabel 2. Uji Debit Aliran Slurry Pada Lokasi Dekat Swivel (Selang 10 m)

\begin{tabular}{|c|c|c|c|c|c|c|c|c|c|}
\hline \multirow{3}{*}{ No } & \multicolumn{9}{|c|}{ Sesaat Keluar Pipa 4", Dekat Swivel } \\
\hline & \multicolumn{3}{|c|}{ Volume $\left(\mathrm{m}^{3}\right)$} & \multirow{2}{*}{$\begin{array}{c}\text { Waktu } \\
\text { (s) }\end{array}$} & \multirow{2}{*}{$\begin{array}{c}\text { Debit } \\
\left(\mathbf{m}^{3} / \mathbf{j a m}\right)\end{array}$} & \multirow{2}{*}{$\begin{array}{c}\text { Luas Pipa } \\
\left(\mathrm{m}^{2}\right)\end{array}$} & \multirow{2}{*}{$\begin{array}{l}\text { Kecepatan } \\
(\mathbf{m} / \mathbf{s})\end{array}$} & \multirow{2}{*}{ Solid:air } & \multirow{2}{*}{$\begin{array}{c}\text { LPT } \\
\left(\mathbf{m}^{3} / \mathbf{j a m}\right)\end{array}$} \\
\hline & Air & Solid & Total & & & & & & \\
\hline 1 & & & 0,14 & 5,44 & 92,73 & 0,0081 & 3,18 & & \\
\hline 2 & 0,1356 & 0,0044 & 0,14 & 4,59 & 109,92 & 0,0081 & 3,77 & $3,23 \%$ & 2,98 \\
\hline 3 & & & 0,14 & 5,30 & 95,04 & 0,0081 & 3,26 & & \\
\hline 4 & & & 0,14 & 5,13 & 98,34 & 0,0081 & 3,37 & & \\
\hline 5 & 0,1290 & 0,0110 & 0,14 & 5,05 & 99,90 & 0,0081 & 3,42 & $8,50 \%$ & 8,25 \\
\hline 6 & & & 0,14 & 4,79 & 105,33 & 0,0081 & 3,61 & & \\
\hline
\end{tabular}


Pengukuran debit aliran slurry hasil pompa tanah setelah melalui selang sepanjang $60 \mathrm{~m}$ untuk kedalaman penggalian 7,5 m menunjukkan debit secara berurutan $111,50 \mathrm{~m}^{3} / \mathrm{jam} ; 128,24 \mathrm{~m}^{3} / \mathrm{jam}$; dan $111,75 \mathrm{~m}^{3} / \mathrm{jam}$. Dengan luas penampang pipa/selang (4 inci) $0,0081 \mathrm{~m}^{2}$ maka diperkirakan kecepatan aliran antara $3,82 \mathrm{~m} / \mathrm{s}$ hingga $4,40 \mathrm{~m} / \mathrm{s}$. (Tabel 3)

Tabel 3. Uji Debit Aliran Slurry Pada Lokasi Dekat Sakan (Selang $60 \mathrm{~m}$ )

\begin{tabular}{|c|c|c|c|c|c|c|c|c|c|}
\hline \multirow{3}{*}{ No } & \multicolumn{9}{|c|}{ Sesaat Keluar Pipa 4", Dekat Sakan } \\
\hline & \multicolumn{3}{|c|}{ Volume (m3) } & \multirow{2}{*}{$\begin{array}{c}\text { Waktu } \\
\text { (s) }\end{array}$} & \multirow{2}{*}{$\begin{array}{c}\begin{array}{c}\text { Debit } \\
\left(\mathbf{m}^{3} / \mathrm{jam}\right)\end{array} \\
\end{array}$} & \multirow{2}{*}{$\begin{array}{c}\text { Luas Pipa } \\
\left(\mathbf{m}^{2}\right)\end{array}$} & \multirow{2}{*}{$\begin{array}{c}\text { Kecepatan } \\
(\mathrm{m} / \mathrm{s})\end{array}$} & \multirow{2}{*}{ solid:air } & \multirow{2}{*}{$\begin{array}{c}\begin{array}{c}\mathbf{L P T} \\
\left(\mathbf{m}^{\mathbf{3}} / \mathbf{j a m}\right)\end{array} \\
\end{array}$} \\
\hline & Air & Solid & Total & & & & & & \\
\hline 1 & & & 0,14 & 4,52 & 111,50 & 0,0081 & 3,82 & & \\
\hline 2 & 0,1325 & 0,0075 & 0,14 & 3,93 & 128,24 & 0,0081 & 4,40 & $5,65 \%$ & 5,98 \\
\hline 3 & & & 0,14 & 4,51 & 111,75 & 0,0081 & 3,83 & & \\
\hline
\end{tabular}

Pengukuran Laju Pemindahan Tanah (LPT) hasil pompa tanah setelah melalui selang sepanjang 60 $\mathrm{m}$ untuk kedalaman penggalian $7,5 \mathrm{~m}$ untuk memenuhi volume sakan $0,863 \mathrm{~m}^{3}$ membutuhkan waktu pengisian senilai $210 \mathrm{~s}$. Dengan luas penampang pipa/selang (4 inci) $0,0081 \mathrm{~m}^{2}$ maka diperkirakan besarnya nilai LPT yaitu $14,88 \mathrm{~m}^{3} / \mathrm{jam}$. Namun berdasarkan perhitungan volume solid dan air dari slurry (Tabel 3) diperoleh nilai LPT sebesar 5,98 $\mathrm{m}^{3} / \mathrm{jam}$, sedangkan di dekat alat BHM (Tabel 2) diperoleh nilai LPT sebesar $2,98 \mathrm{~m}^{3} / \mathrm{jam}-8,25 \mathrm{~m}^{3} / \mathrm{jam}$.

\section{E. DAMPAK TERHADAP LINGKUNGAN}

\section{E.1. Kegiatan Pembangunan Sarana dan Prasarana Tambang}

Kegiatan pembangunan sarana dan prasarana tambang diprakirakan tidak menimbulkan dampak lingkungan yang signifikan karena luas lahan yang disiapkan untuk sarana dan prasarana tambang relatif tidak luas, dan sarana dan prasarana terbatas untuk unit BHM.

\section{E.2. Kegiatan Penambangan Metode Borehole Mining}

Penambangan timah pada Tambang Kecil dengan metode BHM dilakukan dengan cara menyedot lumpur kaksa yang mengandung timah di bawah permukaan pada kedalaman yang direncanakan atau hingga kedalaman sekitar $20 \mathrm{~m}$. Alat yang digunakan untuk menambang dengan metode ini di desain khusus dilengkapi dengan mesin pompa air bertekanan tinggi (jet pump) dan mesin pompa tanah untuk menyedot. Lumpur kaksa hasil sedotan ditampung dalam jumbo bag dan kemudian dibawa ke washing plant untuk meningkatkan kadar Sn. Kapasitas penambangan (laju pemindahan tanah) menggunakan metode BHM yaitu sebesar 2,98 $\mathrm{m}^{3} / \mathrm{jam}$ hingga $14,88 \mathrm{~m}^{3} / \mathrm{jam}$ dengan jam jalan efektif 150 jam/bulan, sehingga kapasitas per bulannya adalah $447-2.232 \mathrm{~m}^{3}$. Pemindahan tanah sebesar $447-2.232 \mathrm{~m}^{3}$ berdampak terhadap penurunan tanah di permukaan sehingga menghasilkan lubang bekas tambang (voids).

Pada rencana kegiatan/aktivitas di tambang, diprakirakan memberikan dampak terhadap komponen lingkungan fisik-kimia: amblesan, erosi dan sedimentasi, pola drainase, bentang alam, dan air limpasan.

\section{a. Amblesan, erosi dan sedimentasi}

Pada saat kegiatan penambangan, lumpur kaksa disedot keluar menggunakan pompa dengan kapasitas $2,98 \mathrm{~m}^{3} / \mathrm{jam}-14,88 \mathrm{~m}^{3} / \mathrm{jam}$, sehingga di bawah permukaan tanah pada kedalaman tertentu akan terdapat rongga dengan volume 2,98 - 14,88 $\mathrm{m}^{3}$ untuk setiap jamnya. Semakin lama alat beroperasi pada titik tersebut, semakin besar rongga yang terbentuk di bawah tanah. Ketika rongga di bawah permukaan tanah ini sudah tidak mampu lagi menopang beban material di atasnya, maka amblesan akan terjadi. Kemungkinan terjadinya amblesan menjadi semakin kuat karena tekstur tanah di lokasi studi umumnya tergolong berpasir dengan struktur berupa 
butir-butir tunggal yang lepas antara satu butir dengan butir lainnya karena rendahnya kandungan bahan organik.

Erosi pada tambang BHM diprakirakan memberikan dampak yang tidak signifikan. Hal ini terjadi karena tambang BHM tidak memerlukan kegiatan pembersihan lahan dan pengupasan tanah pucuk. Bagian permukaan tanah pada tambang BHM relatif tidak terganggu. Lumpur yang disedot pada tambang BHM adalah $8 \mathrm{~m}^{3} / \mathrm{jam}$ dengan break even grade $0,5 \mathrm{~kg} / \mathrm{m}^{3}$, sedangkan sisanya akan dibuang. Partikel-partikel berukuran pasir akan dibuang sebagai sisa hasil pengolahan, sedangkan partikel-partikel berukuran lempung dan debu halus akan terdispersi dalam air dan terbawa arus hingga mencapai tempat-tempat yang berpeluang untuk terjadinya sedimentasi, seperti di pinggir sungai, danau dan muara.

\section{b. Bentang Lahan}

Kegiatan tambang BHM akan menghasilkan rongga-rongga di bawah tanah dengan volume sekitar $447 \mathrm{~m}^{3}-2.232 \mathrm{~m}^{3}$ jika beroperasi selama 150 jam (1 bulan kerja efektif). Permukaan tanah relatif terganggu oleh kegiatan BHM, sehingga mengubah bentang lahan. Sementara itu kegiatan pencucian dan pembuangan sisa penambangan akan sedikit menyebabkan adanya penambahan material timbunan ke permukaan tanah.

\section{c. Pola Drainase}

Pola drainase merupakan pola aliran air yang bisa terbentuk secara alami maupun terbentuk sebagai akibat dari suatu kegiatan. Pola drainase yang terbentuk secara alami merupakan pola aliran air yang terjadi secara alami karena aliran air mengikuti bentuk permukaan bumi atau bentang alam. Pola drainase merupakan salah satu komponen hidrologi lingkungan yang bisa terkena dampak langsung dari kegiatan penambangan. Kegiatan-kegiatan dalam penambangan timah sistem BHM yaitu: penambangan sistem BHM, pencucian dan pembuangan sisa penambangan yang berpotensi berdampak pada perubahan alur sungai yang ada.

\section{d. Air Limpasan}

Pada rencana penambangan baru dengan metode BHM tidak membutuhkan area yang luas namun berpotensi mengganggu permukaan tanah, sehingga menyebabkan peningkatan air limpasan.

\section{F. BENTUK PENGELOLAAN LINGKUNGAN}

Pada wilayah kerja BHM direncanakan pembuatan sirkulasi air tertutup, dimana material slurry/lumpur dimasukkan ke dalam void tertambang. Pengelolaan lingkungan pada wilayah kerja BHM yang menyisakan lubang-lubang (voids) adalah:

1. membuat kolam pengendapan sementara untuk menampung material sisa initial voids;

2. material sisa dari void berikutnya dimanfaatkan untuk menutup void sebelumnya (back-fill);

3. pada final void, material penutup di ambil dari TSP disposal menggunakan alat berat;

4. segera melakukan kegiatan revegetasi pada void yang telah dilakukan backfilling menggunakan tanaman: Seruk (Schima wallichii), Laban (Vitex pubescens), Akasia (Acacia mangium, Acacia auriculiformis), Belangiran (Shorea balangeran), Beringin (Ficus spp), Nyatoh (Palaqium sp), Tukak (Alstonia sp), Bambu (Bambusa sp), Gelam (Melaleuca leucadendron), Sengon (Albizia falcataria), Ketapang (Terminalia cattapa), Kemiri (Aleurites mollucana), Sempur (Dillenia spp.), Pelawan (Tristania obovata),Anggerung (Trema orientalis), Mahang (Macaranga spp).

Ilustrasi strategi pengelolaan lingkungan pada penambangan timah darat menggunakan metode BHM dapat dilihat pada Gambar 5. 


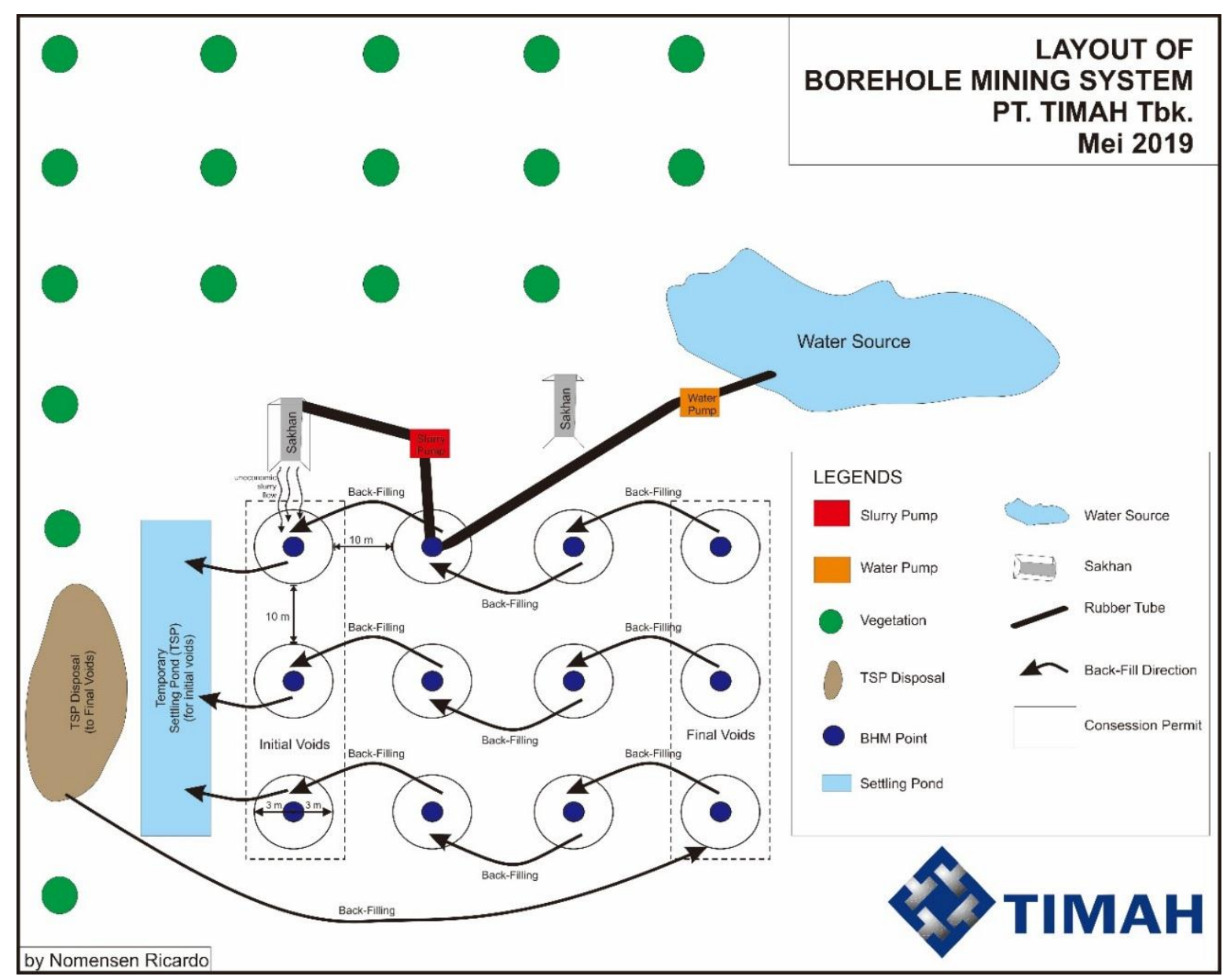

Gambar 5. Iustrasi Strategi Pengelolaan Lingkungan pada Penambangan Timah Darat Menggunakan Metode BHM.

\section{G. KESIMPULAN}

Berdasarkan hasil pembahasan yang mengacu pada tujuan penelitian, maka dapat ditarik kesimpulan sebagai berikut:

1) Penambangan timah pada Tambang Kecil dengan metode BHM dilakukan dengan cara menyedot lumpur kaksa yang mengandung timah di bawah permukaan pada kedalaman yang direncanakan, sehingga dengan adanya kegiatan ini berpotensi menimbulkan permasalahan lingkungan seperti: amblesan, erosi dan sedimentasi, pola drainase, bentang alam, dan air limpasan.

2) Bentuk pengelolaan lingkungan yang dirumuskan pada kegiatan penambangan timah darat menggunakan metode BHM, yaitu: membuat kolam pengendapan sementara untuk menampung material sisa initial voids; material sisa dari void berikutnya dimanfaatkan untuk menutup void sebelumnya (back-fill); pada final void, material penutup di ambil dari TSP disposal menggunakan alat berat; dan segera melakukan kegiatan revegetasi pada void yang telah dilakukan backfilling menggunakan tanaman Sengon, Mahang, Bambu, dan lain-lain

\section{DAFTAR PUSTAKA}

Bojan D., Jan P., Vladimir M., 2004, Selection of technological parameters in borehole mining production by technical deep drilling and hydroexploitation, Acta Montamistica Slovaca, hal. 160-167. 
Bondarchuk I, B., Shenderova I, V., 2004, Classification of Hydraulic Borehole Mining Technological Processes During Pay Zone Development, IOPConf.Series: Earth and Environmental Science.

Ichwan A.L., Robertus B.S., Sasri R., 2014, A Technology Innovation To Converse Tin Alluvial Mining: Subsurface Hydraulic Mining by BTM-SR-4 Equipment, Journal of S\&T Policy \& $R \& D$ Management, Vol.12, hal. 147-156.

Mangga, S.A., dan Djamal B., 1994, Peta Geologi Regional Lembar Bangka Utara, Pusat Pengembangan dan Penelitian Geologi 1994

Margono, U., Supandjono, RJB., dan Partoyo, E., 1995, Peta Geologi Regional Lembar Bangka Selatan, Pusat Pengembangan dan Penelitian Geologi 1995

Romi, S., 2016, DED : BHM Darat Type SR 6 Susunan Umum, Divisi Perencanaan dan Pengendalian Produksi PT.TIMAH Tbk.

Timah Tbk., 2018, Laporan Re-Feasibility Study Pembukaan Tambang Kecil Terintegrasi (TKT) Dengan Borehole Mining, hal 7-12

Timah Tbk., 2018, Laporan Analisis Dampak Lingkungan (AMDAL) : ANDAL, RKL dan RPL 2018 Wilayah Kepulauan Bangka-Belitung

Timah Tbk., 2019, Laporan Kegiatan Pengukuran Debit Aliran Air Dan Slurry Serta Kecepatan Semprotan Air Pada Monitor Alat Borehole Mining (Bhm)Di Lokasi Nudur, Toboali, Bangka Selatan (unpublished) 
PROSIDING TPT XXVIII PERHAPI 2019 